discarded; for it is a question of life and death. The open, disorderly-looking order of march, however slovenly it may seem to the lieutenant-colonel, must here be used, the close order being nothing short of stifling and sickening the men "by Regulation." While on the march, the face and hands should be frequently bathed; and on such halts, which should be ordered every hour, the men should be urged to refrain from drinking the impure waters so general in the hot season. It is hardly necessary to say that the ordinary march should be conducted slowly, and always during the night, when the service will admit of it.

In the French as in the British army, the newly-arrived soldier from Europe has been observed to be the most subject to attacks; and this circumstance would indicate the necessity for an especial precautionary regard to the new-comer and the plethoric. Here, indeed, in the words of Marshal Ney, the attentions of all classes of officers to their men should be unremitting.

In a letter from a distinguished staff-surgeon serving in India in the hot-weather campaign of $1858, \mathrm{I}$ am informed that in his force they lost in a month one hundred or more British soldiers by sun-stroke. The men at length became absolutely terrified of the overwhelming power of the sun, though "not at all of the enemy, for whom they had a great contempt. But all dreaded the sun, and the hospitals became crowded, as well with men really ill as with men ailing but little, and anxious only to escape solar exposure." Here the moral and military effect of the protective helmet of Dr. Julius Jeffreys* would be almost of as great value as its admirable chemical action: it would not only save the lives of some twenty men on the long day's march under an Indian July sun, but it would impart new courage to the drooping battalion. Its influence, small though it looks, would stand in fair comparison, in moral and military power, with that caused by the first sight of Larrey's ambulances on the grenadiers of the French revolutionary armies: "Behold," said they, as they ascended the breach, "we shail no longer be neglected in our wounds and our sickness." Dr. Jeffreys, speaking of his own admirable suggestions, says: "We know too well what the climate of India can do while imperfectly opposed; we have yet to learn what may be the immunities conferred by the most perfect protection at our command."

The protective influence of temperance in diet, as against the dangers of insolation, was never so thoroughly demonstrated as during the recent siege of Delhi, and indeed throughout the hot-weather campaigns, everywhere, against the great Bengal mutiny. Officers before Delhi describe themselves as march. ing all day in the sun of June, July, and August, and serving in the burning trenches for weeks together; and yet they preserved their health, under a temperature of $130^{\circ}$ or more, through temperance, to a wonderful extent.

Grosvenor-street, 1858 .

\section{REPORT OF A CASE OF}

\section{ALLARTON'S OPERATTON FOR STONE: RECOVERY.}

By FREDERICK J. BROWN, M.D., Chatham.

Cephas P-, aged six years, residing in Chatham, was operated upon for stone by me, on the 8th of June last, at half-past ten A.M. The child was put under the influence of chloroform, and a stone was removed from the bladder by the method designated after Mr. Allarton. A No. 3 staff was used, and Poland's forceps (altered in form by being lengthened and narrowed) answered remarkably well. The stone was oval, weighed 125 grains troy, and consisted of phosphate of lime. There was no hæmorrhage. The boy slowly recovered from the effects of the chloroform during the afternoon. There was some tenesmus in the rectum in the evening.

June 9 th. -The boy passed a good night; the urine flows freely by the perineal wound on attempting to micturate, but it does not dribble aw ay at other times ; free from tenesmus unti noon, when he experienced it slightly; the countenance has

* The British Army in India: its Preservation by Appropriate Clothing, Housing, Locating, Reereative Employment, and Hopeful Encouragement of the Troops. With an Appendix. By Julius Jeffreys, F.R.S., Staff-Surgeon at work, by my distinguished friend, should be in the hands of all naval and military surgeons. recovered its colour, having been pale from the effects of the chloroform; tongue clean; eats bread-and-butter and spongecake.

10th.-Passed a good night; he is free from pain, and has no pyrexia; bowels open once, without occasioning much suf. fering; he is amusing himself with toys, sitting up in bed.

11th. - Passed a good night; part of the urine passes through the extremity of the urethra, occasioning smarting; the urine has never dribbled away through the wound, consequently the bed has been dry, and the child's skin unirritated.

12th. - The child awoke at three A.M., crying; pure blood, to the amount of a teacupful, passed by the wound and along the urethra; he complained of pain in the nates and in the right hip; cold chills, with hot skin. Ordered oranges, as an agreeable substitute for saline mixture; fomentations. Three P.M. : Passed urine through the wound and along the urethra; has pain only at intervals, and feels better; he ate a. piece of chop for dinner.

13th. - Passed a good night; has only slight pain occasionally; the urine passes principally along the course of the urethra; bowels open once; a small quantity of blood escaped from the wound during defecation; the pyrexia has disappeared, and his appetite is good.

14th.-Bowels open twice; some blood escaped from the wound during defecation; the wound is healing.

15th. -Doing well; bowels twice open; no bleeding, and. no pain.

16th.-Wound healed to the size of the tip of the little-

finger; some urine still passes through the wound.

17th. - Sitting up.

19th. - Out of doors; no urine has passed through the wound since the 17 th (the tenth day).

25th (eighteenth day). - Wound quite healed, and the child active and running about. Discharged cured.

This child's father was drowned four years ago, at the age of thirty-six years. He had a calculus at the age of twenty. one months, which was extracted by forceps from the extremity of the urethra. He was never again troubled by the complaint.

The child (young Cephas) suffered from symptoms of stone from the age of a fortnight : for instance, he screamed on passing urine. At the age of nine months, he passed a calculus per urethram. Between the ages of nine months and five years, he passed four calculi, making five calculi in all. Blood in considerable quantity escaped with the stone on one occa. sion. The calculus that was removed by operation is the sixth in number, and it was probably of one year's concretion, since no stones escaped from the bladder after the age of tive years.

Chatham, 1858.

\section{git attrror}

OF THE PRACTICE OF

\section{MEDICINE AND SURGERY IN THE}

\section{HOSPITALS OF LONDON.}

Nulla est alia pro certo noscendi via, nisi quam plurimaset morborum es discetionum historias, tam aliorum proprias collectas habere et intersecom parare-Modgate. De Sed,et Caus.Morb.1ib.14. Procmium.

\section{ST. THOMAS'S HOSPITAL.}

RECENT AXILLARY ANEURISM IN A HEALTHY MAT; DELIGATION OF THE SUBCLAVIAN ARTERY IN THE THIRD PART OF ITS COURSE.

(Under the care of Mr. LE Gros Clark.)

THE important operation of deligation of the subclavian artery in the third part of its course, immediately external to the scalenus anticus muscle, we saw performed by Mr. Le Gros Clark on the 5th inst. This was the second time he had done it. In the course of the operation the external jugular vein was seen very prominent, and it was carefully drawn towards the inner side. The omo-hyoid muscle was not once observed. The subclavian artery was readily reached by careful dissection, and the aneurism needle was passed under it from before 